\title{
A new mesoserphid wasp from the Middle Jurassic of northeastern China (Hymenoptera, Proctotrupoidea)
}

\author{
Yan $\mathrm{ZHENG}^{1,{ }^{*}}$ \& Jun $\mathrm{CHEN}^{2}$ \\ ${ }^{1,2}$ Institute of Geology and Paleontology, Linyi University, Shuangling Rd., Linyi 276000, China. \\ ${ }^{2}$ State Key Laboratory of Palaeobiology and Stratigraphy, Nanjing Institute of Geology and \\ Palaeontology, East Beijing Road, Nanjing 210008, China. \\ *Corresponding author: zhengyan536@163.com \\ 22Email: rubiscada@sina.com \\ ${ }^{1}$ urn:1sid:zoobank.org:author:28EB8D72-5909-4435-B0F2-0A48A5174CF9 \\ ${ }^{2}$ urn:lsid:zoobank.org:author:F15C888B-77FC-4F68-9272-E549823DE4CF
}

\begin{abstract}
A new genus and species of Mesoserphidae (Hymenoptera), Juraserphus modicus gen. et sp. nov., is described based on a well-preserved fossil specimen from the Middle Jurassic Jiulongshan Formation of northeastern China. It is characterized by the following forewing features: the forking of $\mathrm{Rs}+\mathrm{M}$ located approximately one-third of the distance between $1 \mathrm{~m}-\mathrm{cu}$ and $2 \mathrm{r}-\mathrm{rs}$, both $1 \mathrm{cu}-\mathrm{a}$ and $2 \mathrm{cu}-\mathrm{a}$ antefurcal; 1-M more than twice as long as $1 \mathrm{~m}$-cu and hind wing with cells $\mathrm{r}$ and rm closed. In addition, it has a short ovipositor, only extending slightly beyond the metasomal apex. Its new morphological characters broaden the diversity of Mesoserphidae in the Mesozoic and provide new insights into the evolution and relationships of Mesoserphidae.
\end{abstract}

Keywords. Mesoserphidae, new taxon, taxonomy, Daohugou, Jiulongshan Formation.

Zheng Y. \& Chen J. 2017. A new mesoserphid wasp from the Middle Jurassic of northeastern China (Hymenoptera, Proctotrupoidea). European Journal of Taxonomy 379: 1-8. https://doi.org/10.5852/ejt.2017.379

\section{Introduction}

The superfamily Proctotrupoidea, a basal group of Prototrupomorpha within Apocrita, includes 11 extant families and one extinct family (Grimaldi \& Engel 2005). Mesoserphidae was erected by Kozlov (1970), representing the only extinct family of Proctotrupoidea. Fossil records of mesoserphids can be traced back to the Middle Jurassic according to the earliest fossil from the upper Middle Jurassic Jiulongshan Formation of northeastern China (Shih et al. 2011). This family was once considered to comprise two subfamilies: Mesoserphinae Kozlov, 1970 and Karataoserphinae Rasnitsyn, 1994 (Grimaldi \& Engel 2005). However, the latest research based on a phylogenetic analysis indicated that these two subfamilies are paraphyletic and should be abandoned (Li et al. 2016).

So far, 22 fossil genera with 53 species have been described worldwide (including their locality, stratigraphic level, external morphological characteristics and body measurements), mostly distributed in 
Kazakhstan, Transbaikalia and China (Kozlov 1968; Rasnitsyn 1983, 1986, 1990, 1994; Zhang \& Zhang 2000; Shih et al. 2011; Shi et al. 2013; Zhang et al. 2013; Li et al. 2016). Among these mesoserphids, 19 species were recorded from the Middle Jurassic, 23 from the Late Jurassic and 11 from the Early Cretaceous (Li et al. 2016). Studies have demonstrated the Mesoserphidae to be highly morphologically divergent, such as in body length (from $1.7 \mathrm{~mm}$ to $12.8 \mathrm{~mm}$ ), forewing length (from $1.5 \mathrm{~mm}$ to 10.4 $\mathrm{mm}$ ), number of antennomeres, wing venation, morphology of the external ovipositor, etc. (Zhang \& Zhang 2000; Shih et al. 2011; Shi et al. 2013; Li et al. 2016).

The new, well preserved specimen was collected from the Jiulongshan Formation (Daohugou, Inner Mongolia, China), famous for its rich fossil insect fauna, including Hymenoptera (Shih et al. 2011; Wang et al. 2014), Coleoptera (Pan et al. 2011; Liu et al. 2015), Diptera (Chen et al. 2014; Shi et al. 2015), Odonata (Zhang et al. 2008; Nel \& Huang 2015) and others (Ren et al. 2009; Chen et al. 2015, 2016). The geological age of this Formation is the latest Middle Jurassic (late Callovian, ca 165-164 Ma), measured by ${ }^{40} \mathrm{~K} /{ }^{40} \mathrm{Ar}$, Ar-Ar and SHRIMP U-Pb (He et al. 2004; Liu et al. 2006; Li et al. 2013).

\section{Material and methods}

The fossil specimen studied herein was collected from the upper Middle Jurassic Jiulongshan Formation at Daohugou Village, Wuhua Town, Ningcheng City, Inner Mongolia, China and is housed in the Shandong Tianyu Museum of Nature in Pingyi County, Shandong Province, China.

The fossil was examined and photographed, both dry and in ethanol, using a VHX 5000 digital microscope platform. Line drawings were prepared with CorelDRAW 14.0 and Adobe Photoshop CS5. The specimen was quantitatively measured using the NIH ImageJ software (http://rsb.info.nih.gov/ij/). The morphological terminology used herein follows Huber \& Sharkey (1993) and Rasnitsyn \& Zhang (2004). Venation symbols: main longitudinal veins are $\mathrm{C}$ (costa), $\mathrm{R}$ (radius), Rs (radial sector), $\mathrm{M}$ (media), $\mathrm{Cu}$ (cubitus) and A (anal vein); crossveins are r-rs (radial crossvein), m-cu (mediocubita crossvein) and cu-a (anal crossvein); cells are $r$, mcu and cua.

\section{Results}

Order Hymenoptera Linnaeus, 1758

Suborder Apocrita Gerstaecker, 1867

Superfamily Proctotrupoidea Latreille, 1802

Family Mesoserphidae Kozlov, 1970

Juraserphus gen. nov.

urn:1sid:zoobank.org:act:38CDA49B-F168-47B0-9CFD-97EE52F82733

\section{Type species}

Juraserphus modicus gen. et sp. nov., designated herein.

\section{Diagnosis}

Forewing 1-Rs as long as 1-M; 1-M more than twice as long as 1m-cu; 2r-rs arising from middle of pterostigma, its width more than twice as long as width of pterostigma; $1 \mathrm{cu}-\mathrm{a}$ antefurcal, $2 \mathrm{cu}-\mathrm{a}$ antefurcal; forking of Rs $+\mathrm{M}$ located approximately one-third of distance bewteen $1 \mathrm{~m}$-cu and $2 \mathrm{r}-\mathrm{rs}$, closer to $1 \mathrm{~m}$-cu; cell $1 \mathrm{mcu}$ complete trapezoid and less than half of cua. Hind wing with cells $\mathrm{r}$ and rm closed. Metasoma spindle-shaped, with elongated segments. Short ovipositor, only extending slightly beyond metasomal apex. 


\section{Etymology}

The generic name is composed of the prefix 'Jura' from the Jurassic period and the suffix of the genus name 'serphus'. The gender is masculine.

\section{Species included}

Type species only.

Juraserphus modicus gen. et sp. nov.

urn:lsid:zoobank.org:act:34160863-3F15-422F-81B7-70971337541C

\section{Diagnosis}

Figs 1-2

As for genus.

\section{Etymology}

The specific epithet is an adjective derived from the Latin word 'modicus', which means 'moderate, average', indicating that both the body and forewing lengths are medium.
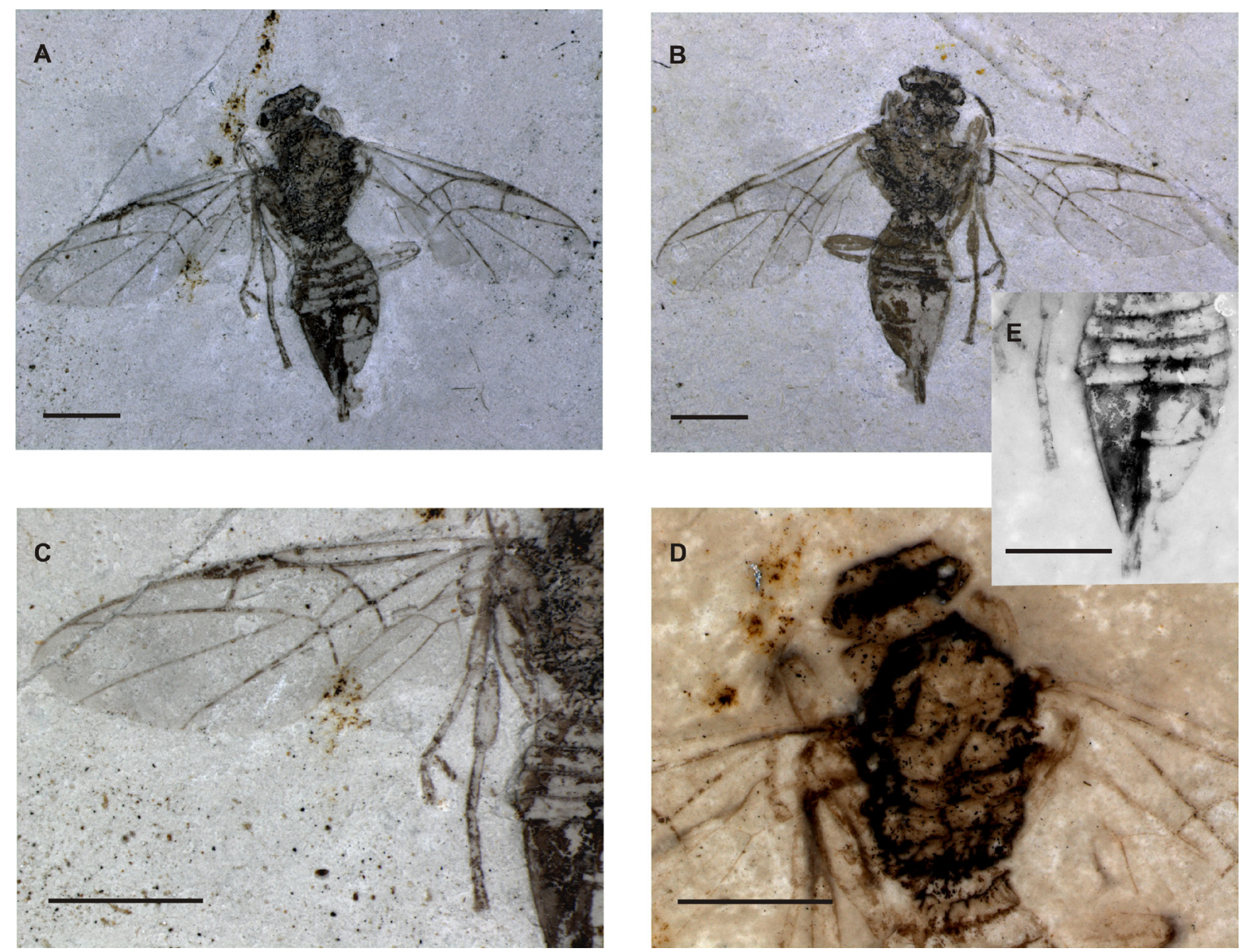

Fig. 1. Holotype of Juraserphus modicus gen. et sp. nov. A. Part. B. Counterpart. C. Left forewing and left hind wing of part. D. Head and mesosoma of part (in ethanol). E. Metasoma of part. Scale bars = $2 \mathrm{~mm}$. 


\section{Material examined}

\section{Holotype}

CHINA: part and counterpart, female in dorsal view (TYNM-48-1244 a-b).

\section{Locality and age}

CHINA: Daohugou Village, Ningcheng County, Inner Mongolia; Callovian (latest Middle Jurassic), Jiulongshan Formation.

\section{Description}

Body length $8.66 \mathrm{~mm}$. Head transversely ovoid, length $1.31 \mathrm{~mm}$ and width $0.63 \mathrm{~mm}$. Eye large, oviod and protruding. Antenna filiform, thin, with nine antennomeres preserved, the first flagellomere long, subsequent flagellomeres gradually decreasing in length from base to apex.

Mesosoma about as wide as head; pronotum trapezoid, extremely short and obviously narrower than head and about 3.6 times as wide as long (length $0.96 \mathrm{~mm}$; width $0.27 \mathrm{~mm}$ ); mesoscutum subquadrate, $0.86 \mathrm{~mm}$ long and $0.37 \mathrm{~mm}$ wide; mesoprescutum length $0.52 \mathrm{~mm}$ and width $0.43 \mathrm{~mm}$; notauli present and reaching transverse mesonotal suture; mesoscutellum triangular; mesopostnotum rectangular, 0.5 times as wide as long; metascutellum preserved and almost as long as wide. Metasoma spindle-shaped,

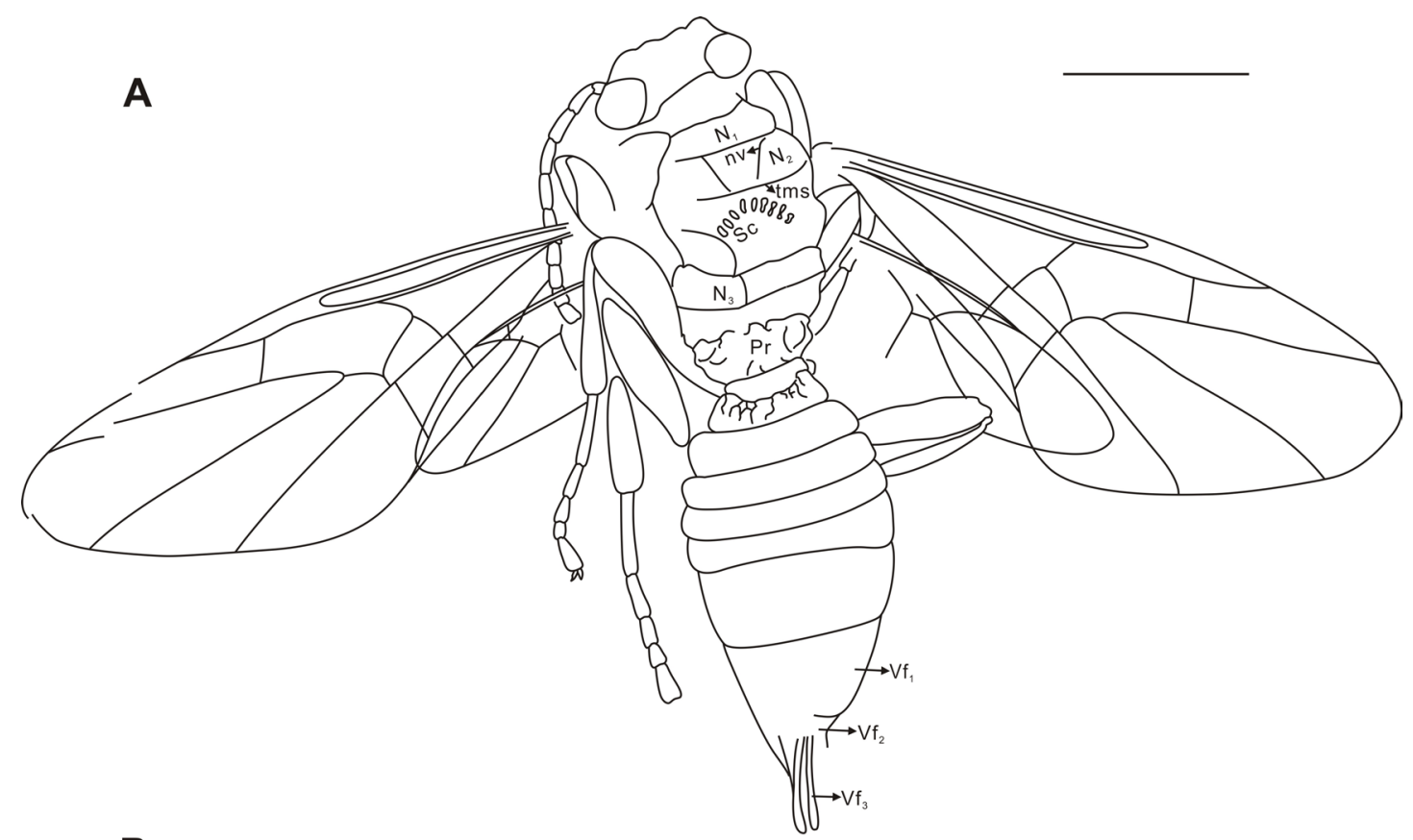

B

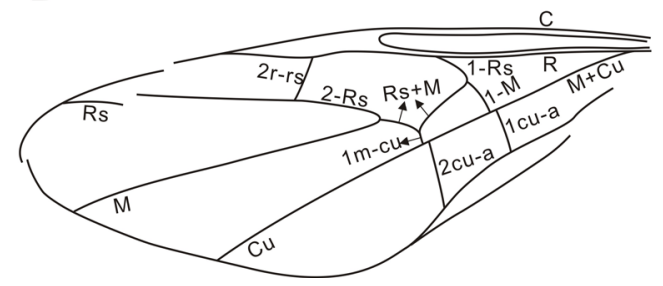

C

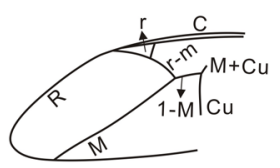

Fig. 2. Line drawings of Juraserphus modicus gen. et sp. nov. A. Habitus. B. Left forewing. C. Left hind wing. Abbreviations: $\mathrm{N}_{1}=$ pronotum; $\mathrm{N}_{2}=$ mesonotum; $\mathrm{N}_{3}=$ metanotum; $\mathrm{nv}=$ notaulus; tms $=$ transverse mesonotal suture; $\mathrm{Sc}=$ mesoscutellum; $\mathrm{Pr}=$ propodeum; $\mathrm{Vf}_{1}=$ valvifer $1 ; \mathrm{Vf}_{2}=$ valvifer 2 ; $\mathrm{Vf}_{3}=$ valvula 3 . Scale bar $=2 \mathrm{~mm}$. 
with seven segments, first observed segment very short, subtrapezoidal; second to fifth segments similar to first in shape and length, but gradually increasing in width; sixth segment reversely trapezoidal and about twice as long as fourth segment; seventh segment about as long as sixth segment; valvifer 1, valvifer 2 and valvula 3 clearly discernible; ovipositor short, slightly stretched out of metasomal apex.

Left foreleg with only femur preserved, small. Left midleg well preserved, with femur wider than tibia; tibia slender; tarsus thin, with basitarsus longest and about twice as long as $2^{\text {nd }}$ tarsomere, $3^{\text {rd }}$ tarsomere obviously shorter than $2^{\text {nd }}, 4^{\text {th }}$ shorter and thinner than $3^{\text {rd }}, 5^{\text {th }}$ twice as long as $4^{\text {th }}$ and possessing two short claws. Left hindleg with femur narrow basally and widened apically, with a spindle-like shape; tibia thicker than midtibia; tarsi similar to midtarsi.

Forewing length $7.05 \mathrm{~mm}$, width $2.73 \mathrm{~mm}$. Pterostigma long and slightly oblique apicad, six times as long as wide. 1-Rs and 1-M equal in length; 1-M more than twice as long as 1m-cu; 2r-rs arising from middle of pterostigma, oblique, about 2.5 times as long as pterostigmal width. Cell $1+2 \mathrm{r}$ five-sided and surrounded by R, 1-Rs, 1-Rs+M, (2-Rs+M) + (2-Rs) and 2r-rs; M+Cu straight and distinct, $\mathrm{M}$ and $\mathrm{Cu}$ straight basally, slightly curved apically; 1-Rs origin at a distance from pterostigma (about twice as long as 1-Rs), and 2r-rs arising from middle of pterostigma; forking of Rs $+\mathrm{M}$ located approximately onethird of distance between 1m-cu and 2r-rs; both 1 cu-a and 2cu-a antefurcal; cell $1 \mathrm{mcu}$ subtrapezoidal, 1.8 times as long as wide basally; $1 \mathrm{cu}-\mathrm{a}$ slightly longer than 1-M and two-thirds of $2 \mathrm{cu}-\mathrm{a}$ in length. Hindwing with long, oblique $\mathrm{r}-\mathrm{m}$ meeting Rs near its base; cell $\mathrm{r}$ long and closed; $\mathrm{M}+\mathrm{Cu}$ and $\mathrm{Cu}$ partly tubular; M tubular.

\section{Discussion}

Various morphological characters of Mesoserphidae have been recorded from the latest Middle Jurassic to Early Cretaceous (Zhang \& Zhang 2000; Shih et al. 2011; Shi et al. 2013; Li et al. 2016). Compared with other mesoserphids, Juraserphus gen. nov. has the rare combination of both 1cu-a and 2cu-a being antefurcal in the forewing, and cells $\mathrm{rm}$ and $\mathrm{r}$ closed in the hindwing. Additionally, Juraserphus gen. nov. is unique among Mesoserphidae in having a female metasoma with five basal terga very short and jointly occupying only half of metosoma's length, whilst the other half is formed by terga 6 and 7 only.

Juraserphus gen. nov. resembles Beipiaoserphus Zhang \& Zhang, 2000 and Basiserphus Li et al., 2016 with both $1 \mathrm{cu}-\mathrm{a}$ antefurcal and $2 \mathrm{cu}-\mathrm{a}$ antefurcal in the forewing, but differs from them in having the forking of Rs $+\mathrm{M}$ located at a distance of one-third between 1m-cu and 2r-rs, and 1-M about twice as long as $1 \mathrm{~m}$-cu (vs one half and 1-M much shorter than 1m-cu in Beipiaoserphus; one-sixth or onequarter and 1-M slightly longer than 1m-cu in Basiserphus). Juraserphus gen. nov has long crossvein 2r-rs, which is more than twice as long as the width of the pterostigma. The length of 2r-rs, however, is less than 1.5 times the width of the pterostigma in Codoserphus Shi et al., 2013 and more than five times as long as the width of the pterostigma in Turgoserphus Rasnitsyn, 1990 (Rasnitsyn 1990; Shi et al. 2013). 1cu-a and 2cu-a of the forewing offer significant characteristics. Juraserphus gen. nov has both 1cu-a and 2cu-a antefurcal, as in Campturoserphus Rasnitsyn, 1986, Scoliuroserphus Rasnitsyn, 1986 and Basiserphus Li et al., 2016, but is different from the latter two and from Lordoserphus Rasnitsyn, 1994 and Sinoserphus Shih et al., 2011 in the 1cu-a and 2cu-a being interstitial, from Apiciserphus Li et al., 2016 in 1cu-a and 2cu-a postfurcal, and from Amboserphus Li et al., 2016 and Yanliaoserphus Shih et al., 2011 in 1cu-a postfurcal and 2cu-a antefurcal (Li et al. 2016). Furthermore, the position of the Rs+M forking in the forewing could be taken as a key feature. The forking of Rs+M is located one-third of the distance between 1m-cu and 2r-rs in Juraserphus gen. nov, whereas it is about one-fifth of this distance in Mesoserphus Kozlov, 1968, Sinoserphus Shih et al., 2011 and Basiserphus Li et al., 2016, and approximately one half in Amboserphus Li et al., 2016 and Beipiaoserphus Zhang \& Zhang, 2000. 
The ovipositor of Mesoserphidae demonstrates significant variations, especially in its length, among the fossils described. The ovipositor in Juraserphus gen. nov. is similar to the one in Novserphus Li et al., 2016 and Ozososerphus Li et al., 2016 in being short, extending beyond the metasomal apex. In contrast, the ovipositor in some other genera (for example, Apiciserphus Li et al., 2016, Amboserphus Li et al., 2016, Udaserphus Rasnitsyn, 1983 and Choriserphus Li et al., 2016) does not extend beyond the metasomal apex. On the other hand, Sinoserphus Shih, Feng \& Ren, 2011 (especially S. grossus Shih, Feng \& Ren, 2011; S. flexilis Shih, Feng \& Ren, 2011 and S. wui Shih, Feng \& Ren, 2011) has a much longer ovipositor, albeit not exceeding half of the metasomal length. Furthermore, the ovipositor in Mesoserphus Kozlov, 1968 is longer than the metasoma.

\section{Acknowledgements}

We express our sincere thanks to Prof. Xiaoting Zheng (Shandong Tianyu Museum of Nature) for donating the specimen described in this paper. Thanks also to Prof. Haichun Zhang (Nanjing Institute of Geology and Palaeontology) for offering constructive suggestions and revising the earlier manuscript. This research is supported by grants from the Scientific Foundation of Shandong Province (ZR2016DB24), the National Natural Science Foundation of China (41502007) and the China Postdoctoral Science Foundation (project 2015M580480).

\section{References}

Chen J., Wang B., Engel M.S., Wappler T., Jarzembowski E.A., Zhang H., Wang X., Zheng X. \& Rust J. 2014. Extreme adaptations for aquatic ectoparasitism in a Jurassic fly larva. eLife 3: e02844. https://doi.org/10.7554/eLife.02844

Chen J., Zhang H., Wang B., Zheng X. \& Wang X. 2015. High variability in tegminal venation of primitive cercopoids (Insecta, Hemiptera), as implied by the new discovery of fossils from the Middle Jurassic of China. Entomological Science 18: 147-152. https://doi.org/10.1111/ens.12103

Chen J., Zhang H., Wang B., Zheng X. \& Wang X. 2016. New Jurassic Sinopalaeocossus and related genera with notes on their evolutionary implications (Hemiptera, Palaeontinidae). Insect Systematics and Evolution 47: 113-129. https://doi.org/10.1163/1876312X-47022136

Grimaldi D. \& Engel M.S. 2005. Evolution of the Insects. Cambridge University Press, New York.

He H.Y., Wang X.L., Zhou Z.H., Zhu R.X., Jin F., Wang F. \& Boven A. $2004 .{ }^{40} \mathrm{Ar} /{ }^{39} \mathrm{Ar}$ dating of ignimbrite from Inner Mongolia, northeastern China, indicates a post-Middle Jurassic age for the overlying Daohugou Bed. Geophysical Research Letters 31: L20609. https://doi.org/10.1029/2004GL020792

Huber J.T. \& Sharkey M.J. 1993. Chapter 3. Structure. In: Goulet H. \& Huber J.T. (eds) Hymenoptera of the World: an Identification Guide to Families: 13-59. Research Branch Agriculture, Ottawa, Canada.

Kozlov M.A. 1968. Jurassic Proctotrupidea (Hymenoptera). In: Panfilov D.V. (ed.) Jurassic Insects of the Karatau: 237-240. Academy of Sciences, Moscow.

Kozlov M.A. 1970. Supergeneric groupings of Proctotrupoidea (Hymenoptera). Entomologicheskoye Obozreniye 49: 203-226.

Li L., Rasnitsyn A.P., Shih C. \& Ren D. 2016. The Mesozoic family Mesoserphidae and its phylogeny (Hymenoptera: Apocrita: Proctotrupoidea). Journal of Systematic Palaeontology 15 (8): 617-639. https://doi.org/10.1080/14772019.2016.1217949

Li L., Shih C. \& Ren D. 2013. Two new wasps (Hymenoptera: Stephanoidea: Ephialtitidae) from the Middle Jurassic of China. Acta Geologica Sinica (English Edition) 87: 1486-1494. https://doi.org/10.1111/1755-6724.12152 
Liu Y., Liu Y., Ji S.A. \& Yang Z. 2006. U-Pb zircon age for the Daohugou Biota at Ningcheng of Inner Mongolia and comments on related issues. Chinese Science Bulletin 51: 2634-2644. https://doi.org/10.1007/s11434-006-2165-2

Liu Z., Slipinski A., Leschen R.A., Ren D. \& Pang H. 2015. The Oldest Prionoceridae (Coleoptera: Cleroidea) from the Middle Jurassic of China. Annales Zoologici 65: 41-52. https://doi.org/10.3161/00034541ANZ2015.65.1.004

Nel A. \& Huang D. 2015. A new family of 'libelluloid' dragonflies from the Middle Jurassic of Daohugou, northeastern China (Odonata: Anisoptera: Cavilabiata). Alcheringa 39: 525-529. https://doi.org/10.1080/03115518.2015.1050316

Pan X., Chang H., Ren D. \& Shih C. 2011. The first fossil buprestids from the Middle Jurassic Jiulongshan Formation of China (Coleoptera: Buprestidae). Zootaxa 2745: 53-62.

Rasnitsyn A.P. 1983. Hymenoptera from the Jurassic of East Siberia. Bulletin of Moscow Society of Naturalists, Biological Series 58: 85-94. [In Russian.]

Rasnitsyn A.P. 1986. New species of the Mesoserphidae hymenopteran family from Upper Jurassic Kara-Tau. Vestnik Zoologii 1986: 19-25. [In Russian.]

Rasnitsyn A.P. 1990. Hymenopterans Vespida. Trudy Paleontologicheskogo Instituta Academii Nauk SSSR 239: 177-205. [In Russian.]

Rasnitsyn A.P. 1994. New Late Jurassic Mesoserphidae (Vespida, Proctotrupoidea). Paleontologicheskii Zhurnal 1994: 115-119. [In Russian.]

Rasnitsyn A.P. \& Zhang H. 2004. A new family, Daohugoidae fam. n., of siricomorph hymenopteran (Hymenoptera $=$ Vespida) from the Middle Jurassic of Daohugou in Inner Mongolia (China). Proceedings of the Russian Entomological Society 75: 12-16.

Ren D., Labandeira C.C., Santiago-Blay J.A., Rasnitsyn A.P., Shih C.K., Bashkuev A., Logan M.A.V, Hotton C.L. \& Dilcher D.L. 2009. A probable pollination mode before angiosperms: Eurasian, longproboscid scorpionflies. Science 326: 840-847. https://doi.org/10.1126/science.1178338

Shi G., Shih C. \& Ren D. 2015. A new genus with two new species of mesosciophilids from the Middle Jurassic of China (Diptera: Nematocera: Mesosciophilidae). Journal of Natural History 49: 1147-1158. https://doi.org/10.1080/00222933.2014.951085

Shi X.Q., Zhao Y.Y., Shih C.K. \& Ren D. 2013. New fossil mesoserphid wasps (Insecta, Hymenoptera, Proctotrupoidea) from the Jehol Biota, China. Zootaxa 3710 (6): 591-599. https://doi.org/10.11646/zootaxa.3710.6.5

Shih C., Feng H. \& Ren D. 2011. New fossil Heloridae and Mesoserphidae wasps (Insecta, Hymenoptera, Proctotrupoidea) from the Middle Jurassic of China. Annals of the Entomological Society of America 104: 1334-1348. https://doi.org/10.1603/AN10194

Wang M., Rasnitsyn A.P. \& Ren D. 2014. Two new fossil sawflies (Hymenoptera, Xyelidae, Xyelinae) from the Middle Jurassic of China. Acta Geologica Sinica (English Edition) 88: 1027-1033. https://doi.org/10.1111/1755-6724.12269

Zhang B.L., Ren D. \& Pang H. 2008. New dragonflies (Insecta: Odonata: Gomphaeschnidae) from the Yixian Formation in Inner Mongolia, China. Progress in Natural Science 18: 59-64. https://doi.org/10.1016/j.pnsc.2007.07.005

Zhang H.C. \& Zhang J.F. 2000. A new genus of Mesoserphidae (Hymenoptera: Proctotrupoidea) from the Upper Jurassic of northeast China. Entomotaxonomia 22: 279-282. 
Zhang H.C., Zheng D.R., Zhang Q., Jarzembowski E.A. \& Ding M. 2013. Re-description and systematics of Paraulacus sinicus Ping, 1928 (Insecta, Hymenoptera). Palaeoworld 22: 32-35. https://doi.org/10.1016/j.palwor.2013.02.001

Manuscript received: 23 December 2016

Manuscript accepted: 13 February 2017

Published on: 14 December 2017

Topic editor: Christian de Muizon

Desk editor: Kristiaan Hoedemakers

Printed versions of all papers are also deposited in the libraries of the institutes that are members of the EJT consortium: Muséum national d'Histoire naturelle, Paris, France; Botanic Garden Meise, Belgium; Royal Museum for Central Africa, Tervuren, Belgium; Natural History Museum, London, United Kingdom; Royal Belgian Institute of Natural Sciences, Brussels, Belgium; Natural History Museum of Denmark, Copenhagen, Denmark; Naturalis Biodiversity Center, Leiden, the Netherlands; Museo Nacional de Ciencias Naturales-CSIC, Madrid, Spain; Real Jardín Botánico de Madrid CSIC, Spain. 